\title{
КРИМІНОЛОГІЧНЕ ПРОГНОЗУВАННЯ
}

\author{
CRIMINOLOGICAL FORECASTING
}

\author{
Тарасевич Ю.В., аспірант \\ кафедри адміністративного та кримінального права \\ Дніпропетровського Національного університету імені Олеся Гончара
}

У статті розглянуто сутність кримінологічного прогнозування та сказано, що під ним розуміють діяльність, що містить в собі обробку та аналіз сукупності відомостей про злочинність задля досягнення певних висновків щодо стану злочинності у певних проміжках часу, певних видів злочинів, ймовірностей скоєння правопорушення певними особами. Визначено поняття мети кримінологічного прогнозування - вироблення різноманітних заходів спрямованих на запобігання криміногенній поведінці засуджених та вчиненню ними кримінальних правопорушень. Автором висвітлено думку, що основою в реалізації кримінологічного прогнозу вважається викриття та взяття на профрілактичний облік засуджених осіб, а також осіб які можуть бути схильні у своїй діяльності до можливої протиправної поведінки в суспільстві, скоєння кримінальних правопорушень, розробка та впровадження заходів індивідуально-профрілактичного превентивного впливу, які у свою чергу нейтралізують ризики вчинення повторних правопорушень. Предметом кримінологічного прогнозування $€$ злочинність, причини її виникнення, особа правопорушення та кримінологічна політика держави. Традиційними видами цієї діяльності $€$ передбачення майбутнього стану злочинності; ії окремих форм, окремих типів правопорушень; індивідуальної поведінки правопорушника; аналітична діяльність спрямована на передбачення розвитку типу людської поведінки в небезпечні форми для суспільства, наслідком якої стане запуск процесу правоутворення, завдяки якому реалізуватиметься кримінально-правова політика держави.

У статті висловлено думку про потребу поряд із загальносоціальною проводити й більш детальну індивідуальну профілактику злочинів та сказано, на початку свого розвитку, в кримінології для вивчення ефективних заходів впливу превентивної діяльності відбирались особи, якими скоєні кримінальні правопорушення, чому в свою чергу передував ряд певних факторів, як наслідок виникає необхідність виявлення тих осіб, які сприятливі до можливого вчинення кримінальних правопорушень. Врегулювання вказаного питання покладено на аналітичну діяльність спрямовану на вивчення окремих видів поведінки правопорушників. Висловлено думку, що прогноз розвитку особи та їі діяльності у суспільстві є вкрай необхідним компонентом персональної профілактики правопорушень, виправлення осіб засуджених за скоєння правопорушень, подальшої їх реадаптації у суспільстві після закінчення строку відбування покарання. Проте на теперішній час виникає необхідність прогнозування поведінки не лише окремих осіб, а окремих груп осіб у який в той чи іншій мірі спостерігаються певні криміногенні ознаки.

Ключові слова: кримінологічне прогнозування, прогнозування злочинності, кримінологічна експертиза, протидія злочинності, екстраполяція, експертні оцінки, моделювання.

The article considers the essence of criminological forecasting and says that it means activities that include processing and analysis of a set of information about crime to achieve certain conclusions about the state of crime at certain intervals, certain types of crimes, the likelihood of crime by certain persons. The concept of the purpose of criminological forecasting is defined - the development of various measures aimed at preventing the criminogenic behavior of convicts and their commission of criminal offenses. The author highlights the opinion that the basis for the implementation of criminological prognosis is the detection and registration of convicts, as well as persons who may be prone in their activities to possible illegal behavior in society, committing criminal offenses, development and implementation of individual preventive measures, which in turn neutralize the risks of recidivism. The subject of criminological forecasting is crime, the causes of its occurrence, the identity of the offense and the criminological policy of the state. The traditional types of this activity are predicting the future state of crime; its separate forms, separate types of offenses; individual behavior of the offender; analytical activities are aimed at predicting the development of the type of human behavior in dangerous forms for society, which will result in the launch of the law-making process, through which the criminal law policy of the state will be implemented.

The article expresses the opinion about the need to conduct more detailed individual crime prevention along with the general social one and says that at the beginning of its development, criminology selected people who committed criminal offenses to study effective measures of preventive activity, which in turn was preceded by a number of factors. as a result, there is a need to identify those persons who are favorable to the possible commission of criminal offenses. The settlement of this issue is entrusted to analytical activities aimed at studying certain types of behavior of offenders. The opinion is expressed that the forecast of development of the person and his activity in a society is an extremely necessary component of personal prevention of offenses, correction of persons condemned for commission of offenses, their further readaptation in a society after the expiration of term of serving of punishment. However, at present there is a need to predict the behavior not only of individuals but of certain groups of people in which to some extent there are certain criminogenic signs.

Key words: criminological forecasting, crime forecasting, criminological examination, crime counteraction, extrapolation, expert assessments, modeling.

Проблеми запобігання злочинності в установах виконання покарань, спонукають обов'язковість розвитку аналізу спрямованого на випередження криміногенної ситуації в середовищі засуджених та вироблення науково обгрунтованих запобіжних заходів. Пріоритетним напрямком внутрішньої політики держави є запобігання злочинності шляхом кримінологічного прогнозування. Попри наявність наукових праць 3 даної проблематики, чіткої систематизації положень кримінологічного прогнозування на даний час не має. Основне визначення включає підхід згідно з яким, вказана діяльність являє собою частину судження про можливі стани об'єкта в майбутньому, охоплюючи усі можливі процеси життєдіяльності суспільства: можливість подальшого наукового та технічного розвитку, економіки, демографічних процесів, розвиток медицини, освіти, культури. Як наслідок об'єктами аналітичної діяльності можуть стати різноманітні сфери суспільства. Поряд із цим особливою галуззю соціального прогнозування $є$ передбачення розвитку явищ та проце-

сів які є кримінологічно-значущими. Крім того, одним із важливих аспектів дослідження питання, пов'язаного iз з'ясуванням змісту кримінологічного прогнозування, $\epsilon$ аналіз основних теоретико-правових аспектів сутності цього поняття як одного зі складових елементів його вдосконалення та забезпечення ефективності, як важливого заходу запобігання злочинності на сучасному етапі розвитку нашого суспільства і держави.

Вивченню вказаного питання присвячені дослідження таких вітчизняних науковців як: Н.А. Алексєєва, Н. Дяченко, В.В. Голіна, Ю.В. Орлов, О.М. Костенко, О.Б. Кірєєва, П.Л. Фріс.

У наукових джерелах термін «прогнозування кримінологічної ситуації» однозначно не визначено, тому проаналізуємо погляди окремих науковців на зміст даного поняття. О.М. Литвинов та С.О. Гладкова [10] стверджують, що ефективна протидія господарським злочинам можлива лише за наявності належного рівня аналітичної діяльності як основного фактора для своєчасного ухва- 
лення необхідних, доцільних висновків на основі прогнозування.

Діяльність пов'язана із кримінологічним прогнозуванням певні науковці вважають соціально-юридичним явищем, оскільки його об'єкт - злочинність - є явище соціально-правове. За висловленням А.М. Бабенко [1], за iii допомогою можна досягати того, щоб система заходів запобігання злочинності (цілі, засоби, методи тощо), іiі внутрішня координація, відповідали не лише теперішнім інтересам та потребам суспільства, а й майбутнім його умовам життя.

Водночас кримінологічне прогнозування превентивної діяльності господарських злочинів, які вчиняються службовими особами, - це аналітична діяльність яка пов'язана з обробкою певної інформації про стан злочинності через деякий проміжок часу, можливість учинення кримінального правопорушення певною особою, задля визначення засобів превентивної діяльності. Виявлення усіх факторів злочинності в майбутньому на певній території, розробка на основі вказаних досліджень негативних тенденцій та виявлення засобів їх зміни у позитивному напрямку $\epsilon$ основною метою цієї діяльності.

М.О. Дунас [5] та А.М. Бабенко [1] дійшли висновку, що прогнозування - являє собою процес наукового передбачення змін тенденцій, кількісних, якісних характеристик злочинності, причин що визначають ії виникнення, особистості правопорушника, превентивної діяльності майбутніх правопорушень, а також розвитком кримінологічної науки. Так, В.В. Голіна [3] вважає, що вказана діяльність полягає у спробах вияснити, яким буде стан злочинності в майбутньому часі. Ю.В. Орлов [11] переконаний, що зміст цього поняття являє собою аналіз можливих злочинних дій та процесів, основою якого становить опрацювання емпіричних даних та облік тенденцій цього розвитку з минулого до майбутнього та від сьогодення до майбутнього.

П.Л. Фріса та В.Б. Харченко [12] переконані, що кримінологічне прогнозування - це пізнання стану злочинності у майбутньому та факторів, які впливатимуть на ii зміни. Різноманітні визначення даного виду можемо знайти у інших кримінологічних джерелах, зокрема в роботах М.Ю. Шуп’яна, І.В. Бестужева-Лади, Г.А. Аванесова.

М.Ю. Шуп'яна акцентує, що для здійснення кримінологічного прогнозування необхідно також враховувати вказану структуру і динаміку злочинності, причини та умови, чинники, впливаючи на динамічні та територіальні зміни, злочинну поведінку окремої особи тощо.

Проте, виходячи зі змісту злочинності, іiі соціальноправової природи та особливостей детермінації та 3 предмета вказаних досліджень, необхідно враховувати, що в науковій літературі щодо такого поняття, як прогноз кримінологічної ситуації, та в цілому пізнань не має (В.В. Вацлавович) [2].

Узагальнюючи отриманні результати науковців і практиків якими вивчалось поняття кримінологічного прогнозу можна дійти до висновку, що під поняттям прогнозу кримінологічної ситуації $\epsilon$ аналітична діяльність спрямована на вивчення зміни та розвитку злочинності чи вірогідності вчинення правопорушень певними особами у різні проміжки часу (майбутньому) у певних територіальних межах, враховуючи різноманітні фактори, які іiі детермінують.

У процесі кримінологічного прогнозування необхідно брати до уваги «поправочні коефіцієнти» у вигляді запланованих законодавцем акцій й криміналізації або декриміналізації певних видів злочинів. Ігнорування ролі законодавця, його внеску у визначення кола злочинного і кримінально-караного може суттєво знизити його цінність та інформативність (В. В. Голіна) [4]

Предметом кримінологічного прогнозування $є$ злочинність, їі детермінанти, особа злочину та кримінологічна політика держави (Н. Дяченко) [6]. Згідно 3 предметом кримінології, основою цієї діяльності є встановлення найпоширеніших показників, які зможуть характеризувати динаміку розвитку злочинності через деякий час.

Науковцями термін кримінологічного прогнозування висвітлюється як певна діяльність спрямована на наукове передбачення різноманітних тенденцій, закономірностей розвитку злочинності в цілому, так і певних категорій, особистості правопорушника, кримінальної поведінки, детермінуючих злочинність факторів, кримінологічної політики.

Таке прогнозування здебільшого відповідає на питання: як змінюються ті чи інші фактори в залежності від певних змін причин і умов, які їм сприяють, які фактори і як вони можуть вплинути на злочинність; які саме особи можуть стати потенційними правопорушниками, яке співвідношення між певними завданнями боротьби зі злочинністю та найефективнішими заходами на вказаному напрямі. У своїй діяльності воно буває як науково обгрунтованим так і звичайним. Крім того необхідно зазначити, що науковий прогноз може розробляється за допомогою системних інформацій о злочинності, ії причин та окремих видів правопорушень, ряду факторів що впливають на злочинну поведінку, в основі цієї діяльності полягають загальнонаукові й спеціальні наукові методи прогнозування. Враховуючи викладене можна дійти висновку, що науковий прогноз - являє тобою не тільки суб'єктивну думку про те що буде у майбутньому, а здійснення на постійній основі вивчення певних явищ, процесів за допомогою досягнень сучасної кримінології [7].

Індивідуальне кримінологічне прогнозування, у своїй основі, має базуватись на чотирьох методиках, які сприятимуть вирішенню поставлених завдань, це: методика ретроспекції; діагностики; прогнозу; практичного прогнозування.

При аналізі злочинності необхідно враховувати ряд факторів, які впливають на повноту та вірогідність результатів аналізу. По-перше, статистика злочинності враховує не всі вчинені злочини, а лише ті, які були виявлені й зареєстровані правоохоронними органами. По-друге, у зв'язку з тим, що статистичні показники відображають відомості про злочини не на момент їх вчинення, а на момент встановлення, виявлення, відбувається зсув у часі моменту реєстрації даних про злочини та осіб, які вчинили злочини, від моменту вчинення злочинів. По-трете, статистична інформація про осіб, що вчинили злочини, може значно запізнюватись відносно інформації про злочини у зв'язку 3 тим, що особи можуть бути встановлені набагато пізніше реєстрації злочинів.

Принципи прогнозування: системність та узгодженість. Функції: орієнтовна (щодо встановлення направлення діяльності); нормативна (щодо нормативного врегулювання діяльності). Функції прогнозу: - виявлення характеру зміни певної ситуації в умовах, коли на неї діють впливи, що стихійно складаються; - аналіз зміни ситуації в умовах, коли на неї впливає певна дія, коли відомі цілі і засоби його здійснення; - визначення характеру ситуації, з якої необхідно виходити для досягнення поставленої мети; - виявлення зміни окремих цілей, засобів при досягненні головної мети. Усі ці види прогнозування - не що інше, як одержання інформації про явища, що не існують в момент, коли робиться прогноз [9].

При прогнозуванні розвитку злочинності найчастіше використовують наступні основні методи: екстраполяції, експертної оцінки, математичного моделювання [10].

1. Метод екстраполяції, який $є$ математичним та полягає у тому, що злочинність, ії тенденції, вивчаються здебільшого у минулому та теперішньому часі, а отримані результати використовуються для розроблення прогнозів на майбутне. Разом $з$ тим, його основним недоліком $€$ забезпечення достовірності лише на короткий проміжок часу при стабільних суспільних відносинах.

2. Метод математичного моделювання щільно пов'язаний з екстраполяцією є більш точнішим, оскільки 
продовження в майбутнє встановлених тенденцій припускає вибір визначеної моделі екстраполяції (лінійної, нелінійної, множинної корекції тощо). Вказаний метод вважається найбільш досконалим, але водночас складним, оскільки охоплює систему математичних формул спрямовану на обробку динаміки злочинності у взаємодії з певними факторами які на неї впливають. Основною складністю цього методу слід вважати недостатню вивченість усіх детермінуючих злочинність факторів, механізму їх взаємодії та сили впливу кожного 3 них на злочинність та безпеку людини.

3. Метод експертних оцінок є універсальним оскільки 3 його допомогою можливо як зібрати усю прогностичну інформацію, а на підставі неї сформулювати прогнозований висновок. 3 метою його найбільш ефективного використання можуть залучатись у якості експертів кваліфіковані спеціалісти у певних галузях, які у свою чергу виражаючи свою думку використовують не лише офіційні дані, а й свої професійні навики. Вказаний метод найефективніше використовується при середньостроковому та довгостроковому прогнозуванні.

Відповідно до завдань прогнозування поділяється на певні часові проміжки, з яких виділяють: поточне (на декілька днів через можливі значні події на окремій територіі), короткострокове (переважно на 1-2 роки), середньострокове (як правило на 3-5 років) та перспективне (використовується переважно науковцями, експертами на 5-10 років).

Для ефективної роботи правоохоронних органів в регіонах, як правило найефективнішим є метод екстраполяції (перенесення виявлених закономірностей на майбутнє). Засіб експертних оцінок (погляд фахівців, заснований на фаховому, науково-практичному досвіді) рекомендується використовувати у великих регіонах, де, зазвичай, достатня кількість учених, спеціалістів, фахівців, спроможних виступити експертами з проблем розвитку ситуації.

За експертними оцінками, в Україні тенденцію до збільшення злочинів у сфері господарської діяльності мають: розкрадання бюджетних коштів - $12 \%$, незаконна приватизація - 9\%, шахрайство 3 фінансовими ресурсами $-7 \%$, ухилення від сплати податків - $22 \%$, зловживання у банківській сфері - $12 \%$, зловживання на споживчому ринку $-7 \%$, відмивання грошей $-5 \%$ тощо.

За допомогою оцінок експертів у поєднанні 3 методом екстраполяції можливо зробити прогноз злочинності як загалом, так і за окремими іiі видами. Найскладнішим слід відзначити метод моделювання. Він дозволяє зробити висновки про очікувані зміни щодо злочинності, уможливлює передусім зібрання всіх демографічних, економічних та інших факторів, які можуть впливати на розвиток злочинності у регіоні.

Враховуючи вищевикладене можна дійти висновку що таке явище, як кримінологічне прогнозування являє собою певну діяльність задля обробки, аналітичної діяльності 3 кримінологічною інформацією метою якої є отримання інформації про стан злочинності через певні проміжки часу, ймовірність скоєння правопорушення певними особами. У свою чергу поняття кримінологічного прогнозу являє собою вже отримані висновки, за наслідками вищевказаної діяльності

\section{ЛITEPATYPA}

1. Бабенко А.М. Кримінологічне прогнозування як основа для планування запобігання злочинності в регіонах // Право та державне управління 2014. № 3 (16). С. 60-63.

2. Вацлавович В.В. Теоретичні проблеми кримінологічного прогнозування // Право. 2012. № 5. С. 53-64.

3. Голіна В.В., Лукашевич С. Ю., Колодяжний М. Г. Державне програмування і регіональне планування заходів запобігання злочинності в Україні / за заг. ред. В.В. Голіни. Харків: Право, 2012. 304 с.

4. Голіна В.В. Кримінологічна політика як основа розробки теорії і практики запобігання злочинності в Україні. 2016. 192 с.

5. Дунас М. О. Організаційно-правові проблеми з організації запобігання злочинів у сфері господарської діяльності, що вчиняються службовими особами // Приватне та публічне право. № 1. 2019. С. 148-152.

6. Дяченко Н. Прогнозування як функція державного управління / Н.Дяченко // Проблеми управління соціальним і гуманітарним розвитком. за заг. ред. О.Б. Кірєєвої. Дніпро: ДРІДУ НАДУ, 2017. С. 71-74.

7. Єдиний звіт про кримінальні правопорушення за 2013-2019 рр. К.: ГПУ, 2019. 250 с

8. Концепція адміністративно-правового забезпечення протидії корупції в Україні / В.І. Литвиненко, П.Я. Пригунов. К.: ДП «Вид. дім «Персонал», 2016. 89 c.

9. Кримінологія: підручник, практикум / В.С. Ковальський, О.М. Костенко, Г.С. Семаков та ін. К.: Юрінком Інтер, 2017. 344 с.

10. Литвинов О.М., Гладкова Є.О. Кримінологічна футурологія: постановка проблеми. Вісник Кримінологічної асоціації України: зб. наук. праць. № 2 (23). 2020. С. 129-137.

11. Орлов Ю.В. Планування кримінологічне. Вісник Асоціації кримінального права України. 2016. № 2 (7). С. 358-360.

12. Політика у сфері боротьби зі злочинністю України: теретичні та прктичні проблеми: монографія/ за заг. ред. проф. П.Л. Фріса тапроф. В.Б. Харченка. Івано-Франківськ - Харків: Прикарпатський нац. ун-т імені Василя Стефаника, 2016. С. 162-178. 